\title{
Evaluasi Cambridge International Primary Programme Siswa SD Al Azhar pada Mata Pelajaran Sains dalam Bahasa Inggris
}

\author{
Ria Herwandar, Denny Azhari Safryono \\ Program Studi Sastra Inggris, Fakultas Sastra \\ Universitas Al Azhar Indonesia, Jl.Sisingamangaraja, Jakarta 12110 \\ Penulis untuk korespondensi/E-mail: ria_herwandars@uai.ac.id
}

\begin{abstract}
Abstrak - Penelitian ini memiliki judul Evaluasi Cambridge International Primary Programme Siswa SD Al Azhar pada Mata Pelajaran Sains dalam Bahasa Inggris'. Tujuan dari penelitian ini adalah untuk mengidentifikasi tingkat pemahaman dan kelancaran dalam melakukan ujian sains yang berisi bahan ESP / EAP. Hasilnya sangat tak terduga menjanjikannya. Siswa telah mencapai hasil yang baik di semua bidang ilmu pengetahuan seperti biologi, kimia, fisika dan penyelidikan ilmu pengetahuan dan telah terbukti bahwa siswa di usia tua bisa belajar dan memperoleh bahasa kedua dan bahasa pertama di dasar kesetaraan sekitar tiga belas tahun. Oleh karena itu, peserta didik muda harus intensif bahasa Inggris dalam membantu mereka mengembangkan pelajaran sekolah lainnya dalam kurikulum utama Inggris.
\end{abstract}

Kata Kunci - Science enquiry, biologi, kimia, fisika, ESP/EAP

Abstract - This research has a title of 'Evaluation Cambridge International Primary Programme for Pupils of Al Azhar in Science'. The purpose of the research is to identify their level of understanding and fluency in doing science examinations which contains ESP/EAP materials. The results have been unexpectedly promising. The pupils have achieved good results in all areas of science such as biology, chemistry, physics and science enquiry and it has been proved that pupils in the age of around thirteen years old could learn and acquire second language and first language in equal basis. Therefore, Young learners should be intensively exposed to excellent English language learning in helping them developed other school subjects within the English primary curriculum.

Keywords - Science enquiry, biology, chemistry, physics, ESP/EAP

\section{PENDAHULUAN}

$\mathrm{P}$ enelitian ini merupakan penelitian lanjutan dari penelitian berjudul Evaluasi Cambridge International Primary Program Siswa SD Al-Azhar pada Mata Pelajaran English Language. Peneliti, pada penelitian ini, mengulas masalah kemampuan para siswa dalam menghadapi ujian sains dalam bahasa Inggris.

Setelah Undang-undang Republik Indonesia No 20 tahun 2003 tentang Sistim Pendidikan Nasional sebagai dasar hukum penyelenggaraan dan reformasi sistim pendidikan nasional, pasal 50 ayat 3 menyatakan bahwa " Pemerintah dan/atau Pemerintah Daerah menyelenggarakan sekurang- kurangnya satu satuan pendidikan pada semua jenjang pendidikan untuk dikembangkan menjadi satuan pendidikan yang Bertaraf Internasional", maka kegiatan menerapkan pengajaran cambridge semakin ditingkatkan.

Kelas bilingual tingkat SD, SMP dan SMA merupakan langkah persiapan untuk menuju RSBI, dan sesuai dengan visi dan misi pendidikan nasional yang menekankan bahwa pendidikan nasional harus mampu mengembangkan manusia Indonesia yang berkualitas sehingga mampu dan proaktif menjawab tantangan zaman yang selalu berubah dengan cepat [1]. Pendidikan diharapkan mampu menciptakan manusia yang siap bersaing di tingkat regional , nasional dan internasional. 
Walaupun Undang-undang Republik Indonesia No 20 tahun 2003 tentang Sistim Pendidikan Nasional yang menerapkan penyelenggaraan satuan pendidikan bertaraf Internasional dihapuskan, banyak sekolah yang tetap meneruskan pelaksanaan RSBI ini secara mandiri karena dianggap sangat dibutuhkan untuk mempersiapkan anak didik agar mampu bersaing didunia kerja.

Ketika Program Rintisan SMA Bertaraf Internasional diterapkan di SMA Al Azhar dengan melibatkan pola pendidikan Cambridge International Examination, para pimpinan Yayasan Pendidikan Al Azhar akhirnya menetapkan pula bahwa kurikulum Cambridge harus diawali mulai dari jenjang pendidikan yang paling bawah yaitu di tingkat SD agar menjadi satu kesatuan pendidikan yang lengkap dan berkesinambungan sampai SMA.

Dengan pemikiran diatas, maka Pimpinan Yayasan Pendidikan al Azhar, mendaulatkan pimpinaan Cambridge International Examination di Al Azhar menyelanggarakan bukan saja program ujian Cambridge untuk tingkat SMA yang dinamakan IGCSE, tetapi juga membuka ujian Cambridge ditingkat SD dengan menerapkan Primary Cambridge Education. Walaupun kurikulum local tidak diubah, namun dengan dimasuknya komponen silabus dan kurikulum Cambridge ke dalam kurikulum local maka perubahan yang terjadi di tingkat SD sampai dengan SMA tentu menjadi suatu pekerjaan yang cukup besar yang harus dikerjakan oleh sekolah sekolah Al Azhar di Jakarta.

Pada tahun 2012 sebanyak 61 siswa SD Al-Azhar mengikuti ujian cambridge bahasa Inggris dan mendapat nilai yang cukup baik secara keseluruhan. Berikut ini adalah komentar mengenai kemahiran siswa yang telah dicapai berdasarkan penilaian Cambridge.

Tabel 1. Komentar mengenai kemahiran siswa yang telah dicapai berdasarkan penilaian Cambridge

\begin{tabular}{|c|c|c|}
\hline \multicolumn{3}{|l|}{ Reading } \\
\hline$R x$ & Explicit Meaning & Performance was better than expected \\
\hline$R i$ & Implisit Meaning & Performance was better than expected \\
\hline$R u$ & Use of language & Performance was better than expected \\
\hline \multicolumn{3}{|l|}{ Usage } \\
\hline$U p$ & Punctuation & Performance was as expected \\
\hline$U n^{*}$ & Sentence structure & Performance was worse than expected \\
\hline Us & Spelling & Performance was as expected \\
\hline$U v$ & vocabulary & Performance was as expected \\
\hline \multicolumn{3}{|l|}{ Writing } \\
\hline$W c$ & content & Performance was as expected \\
\hline Wa* & Purpose and audience & Performance was worst than expected \\
\hline$W n^{*}$ & text structure & Performance was worst than expected \\
\hline
\end{tabular}

\section{Pembatasan Masalah}

Permasalahannya adalah bagaimana hasil ujian mata pelajaran sains dalam program Cambridge Primary berhasil dilaksanakan, mengingat siswa SD adalah siswa yang baru berumur 6 tahun sampai dengan 12 tahun. Kondisi biologis, otak dan kognitif bahasa mereka baik ditingkat bahasa pertama maupun ke dua masih tumbuh kembang. Bagaimana siswa dapat mengerti dan memahami bahasa Inggris yang diperuntukkan khusus untuk dunia sains. Bahasa Inggris dibidang ilmu sains berarti penguasaan bahasa Inggris siswa sudah menyentuh ranah English for Specific Purposes ESP atau English for Academic Purposes. Dapatkah mereka memiliki kemampuan yang diharapkan sesuai benchmark Cambridge Primary untuk mata pelajaran sains. Sementara kemampuan bahasa Indonesia sebagai bahasa pertama dan kemampuan bahasa Inggris sebagai bahasa ke dua juga masih dalam proses pencapaian yang belum sempurna. Bagaimana capaian keberhasilan tes sains dalam bahasa Inggris dan faktor apa saja yang mempengaruhi keberhasilan di bidang mata pelajaran sains.

Masalah ini dapat terungkap melalui penelitian data data yang akan dikumpulkan baik data kepustakaan sebagai kajian teori yng terdahulu, pemerolehan bahasa pertama dan kedua pada anak dan pengetahuan psikolinguistik pemerolehan bahasa pada anak dan Second language Acquisition, berkaitan dengan assessment pemerolehan bahasa ke dua. Peneliti akan menganalisis English for Specific Purposes ESP dan English for Academic Purposes EAP berkaitan dengan isi mata pelajaran sains dalam bahasa Inggris .Dalam mencari data tidak sebatas data teori tetapi juga menganalisis kurikulum dan silabus Cambridge Primary di bidang sains, materi dan data hasil ujian Cambridge Primary Examination siswa Al-Azhar dalam bidang sains.

\section{Perumusan Masalah}

Apa yang dimaksud dengan English for Specific Purposes (ESP) dan English for Academic Purposes (EAP).

1. Bagaimanakah bentuk kurikulum dan silabus Cambridge dalam pelajaran sains untuk sekolah dasar.

2. Materi ESP/EAP seperti apa yang ada dalam ujian sains (SD) dalam bahasa Inggris

3. Bagaimana hasil ujian Cambridge sebagai capaian pembelajaran sains

4. Faktor apa saja yang mempengaruhi hasil ujian sains sekolah dasar 


\section{Tujuan Penelitian}

Tujuan umum dari penelitian ini adalah melihat tingkat kesulitan dan hasil capaian ujian sains siswa SD Al-Azhar, dikaitkan dengan kemahiran pemerolehan bahas ke dua pada anak usia 12- 13 tahun. Dengan demikian, penelitian ini mengkhususkan pengamatan pada kegiatan seperti:

1. Menjelaskan apa yang dimaksud dengan English for Specific Purposes (ESP) dan English for Academic Purposes (EAP).

2. Mendeskripsikan bentuk kurikulum dan silabus pelajaran sains untuk sekolah dasar.

3. Menganalisis materi ESP/EAP seperti apa yang ada dalam ujian sains (SD) dalam bahasa Inggris

4. Menjelaskan hasil ujian Cambridge sebagai capaian pembelajaran sains

5. Menganalisis faktor apa saja yang mempengaruhi hasil ujian sains sekolah dasar

\section{Manfaat Penelitian}

Manfaat dari hasil penelitian yang akan didapat adalah pemahaman secara mendalam mengenai hasil pembelajaran sains dalam bahasa Inggris yang mengacu pada kurikulum dan silabus Cambridge International Examination untuk sekolah dasar 1-6 [2]. Kedua bagaimana pengaruh bahasa Inggris terhadap capaian mata pelajaran sains bagi anak sekolah dasar sampai usia 12, atau 13 tahun. Dengan pemahaman ini para guru dapat mengetahui apa yang harus diajarkan kepada anak baik dari segi bahasa maupun sains dengan baik dan tepat sasaran. Mungkin untuk pembahasan kedepan akan ditelusuri bagaimana merancang pembelajaran ESP dan EAP untuk tingkat sekolah dasar dan penyuluhan yang efektif bagi keberhasilan yang lebih besar dalam pembelajaran pemerolehan sains dalam bahasa Inggris bagi siswa SD. Al Azhar dan SD lainnya di Indonesia.

\section{KAJIAN TEORI/TINJAUAN PUSTAKA}

\section{Pola English for Specific Purposes dan English for Academic Purposes}

Dalam mempelajari bahasa Inggris, ada beberapa ungkapan yang merujuk kepada cara bagaimana melihat posisi penutur bahasa yang memakai bahasa tersebut dan cara mempelajari bahasa terutama sebagai penutur asing dalam bahasa Inggris. Beberapa contoh antara lain misalnya; English as a Second Language (ESL) bahasa Inggris sebagai bahasa kedua; English as a Foreign Language (EFL), bahasa Inggris sebagai bahasa Asing, dan English as First Language atau bahasa penutur jati. Ungkapan yang dijelaskan ini memperlihatkan posisi penutur bahasa yang berbeda beda dan juga memperlihatkan kemampuan penutur bahasa yang berbeda pula. English as First language atau penutur jati tentu lebih mahir berbicara dibandingkan dengan penutur English as a Second Language. Penutur ESL akan lebih mahir dibandingkan dengan penutur EFL tentunya, karena bagi penutur EFL, bahasa Inggris merupakan bahasa asing yang digunakan hanya ketika diperlukan saja seperti bertemu orang asing dan ketika berada diluar negeri. Penutur EFL melihat bahasa Inggris sebagai bahasa asing .sedangkan penutur ESL melihat bahasa Inggris sebagai bahasa kedua yang lebih dekat melekat pada dirinya dan digunakan dalam kehidupan sehari hari misalnya disekolah. Penutur ESL inilah yang berlaku bagi murid yang belajar disekolah bilingual ataupun sekolah internasional.

Dari sudut pandang cara atau metodologi pembelajaran bahasa Inggris dibagi menjadi General English atau belajar bahasa Inggris secara umum dan ini cocok untuk mereka yang berada di tingkat EFL. English for Specific Purposes diperuntukkan bagi pembelajar bahasa dengan jangkauan yang lebih luas misalnya bahasa Inggris untuk pegawai bank, atau otomotif disebuah perusahaan, sehingga metodologi pengajarannya harus sesuai dengan kebutuhan yang spesifik baik dilihat dari tatabahasa, lesikal, register, wacana maupun genrenya. ESP diperlukan bagi pembelajar yang berada di tingkat intermediate dengan memiliki dasar bahasa tersebut untuk dapat memahami pembelajaran yang lebih spesifik. [3]

Sementara English for Academic Purposes merupakan kemahiran berkomunikasi dalam bahasa Inggris untuk keperluan pembelajaran dalam sistem pendidikan formal, yang digunakan pertama kali di tahun 1974 dan menjadi lebih populer dengan terbitnya prosiding Seminar di Birmingham University tahun 1975 mengenai The Language Problems of Overseas Students in Higher education in the $U K$ dan diberi judul English for academic Purposes [3].

Pada intinya Richard dan Renandya menjelaskan bahwa baik ESP dan terutama EAP metode pengajaran harus berbasis pengajaran contentbased dan meluas ke project-based. Raimes dalam Richard dan Renandya menambahkan pentingnya process writing dalam ESP maupun EAP. Kriteria yang ada dalam ESP dan EAP tercermin dalam kurikulum Cambridge walau tingkat akademik 
yang ada dalam kurikulum Cambridge di bidang saint masih sangat mendasar [4].

\section{Kurikulum Pendidikan Dasar Cambridge di Bidang Sains}

Faktor penting lainnya yang akan dianalisis adalah Science Curriculum Framework of Cambridge Primary Check Point. Kerangka kurikulum ini berlandaskan gabungan antara kurikulum nasional Inggris dan kurikulum Internasional sesuai dengan karakter pengguna kurikulum Cambridge yang terdiri dari siswa di seluruh dunia. Kerangka kurikulum The Cambridge Primary for Science di bagi menjadi 6 tahapan ( kelas 1-6) dengan kisaran umur mulai 5 tahun pada stage 1 sampai umur 11 tahun pada stage 6 . Ujian dilaksanakan pada tingkat akhir di kelas 6. Perkembangan bahasa baru di ujikan di kelas 3, 4, 5 dan 6. Agar guru dapat memonitor perkembangan siswa. Ujian yang berbentuk progress test bukan untuk menaikkan atau menggugurkan siswa tetapi cukup berupa paparan perkembangan pembelajaran. Kerangka kurikulum di bagi menjadi 4 kelompok yakni:

\begin{tabular}{|c|c|c|c|}
\hline SCIENTIFIC & BIOLOG & CHEMISTR & PHYSIC \\
ENQUIRY & $\mathrm{Y}$ & $\mathrm{Y}$ & $\mathrm{S}$ \\
\hline
\end{tabular}

Contoh cuplikan kurikulum SCIENCE kelas 5 adalah sebagai berikut [2]:

\section{Scientific Enquiry}

Scientific Enquiry-ideas and evidence

1. Knows that scientists have combined evidence with creative thinking to suggest new ideas and explanations for phenomena.

2. Use ovservation and measurement to test predictions and make links

\section{Scientific Enquiry-plant investigative work}

1. Make Predictions of what will happen based on scientific knowledge and understanding and suggest and communicate how to test these.

2. Use knowledge and understanding to plan how to carry out a fair test

3. Collect sufficient evidence to test an idea.

4. Identify factors that need to be taken into account in different contexts

\section{Scientific Enquiry-obtain and present evidence}

1. Make relevant observations.

2. Measure volume, temperature, time, length and force.

3. Discuss the need for repeated observations and measurements.

4. Present results in bar charts and line graphs
Scientific Enquiry-consider evidence and approach

1. Decide whether results support predictions.

2. Begin to evaluate repeted results.

3. Recognise and make predictions using scientific knowledge and understanding.

4. Interprete data and think about whether it is sufficient to draw conclutions.

\section{Biology}

Plants

1. Know that plants need energy from light for growth.

2. Know that plan reproduce.

3. Observe that plants produce flowers which have male and femaleorgans, seeds are formed when pollen from the male organ fertilises the ovum (female).

4. Recognise that flowering plantshave a life cycle including pollination, fertilisation, seed production, seed dispesal and germination.

\section{Chemistry}

States of matter

1. Know that evaporation occurs when a liquid turns into a gas.

2. Know that condensation occurs when a gas turns into a liquid and that it is the reverse of evaporation.

3. Know that air contains water vapour and when thismeets a cold surface it may condence.

4. Know that the boiling pointof water is $100 \mathrm{C}$ and the melting pointof ice is $O C$.

5. Know that when a liquid evapourates from a solution the solid is left behind.

\section{Physics}

Light

1. Observe that shadows are formed when light travelling from a source is blocked.

2. Investigate how the size of a shadow is affected by the position of the object.

3. Observe thatshadows change in length and position throughout thecday.

4. Know that light intensity can be measured.

5. Explore how opaque materials do not let light through and transparent materials let a lot of light through.

6. Know that we see light sources because light from the source enters our eyes.

7. Know that beams/ rays of light can be reflected by surfaces including mirror, and when reflected light enters out eyes we see the objects.

8. Explore why a beam of light changes direction when it is reflected from a surface. 


\section{The Earth and beyond}

1. Explore, through modeling, that the sundoes not move; its apparent movement is caused by the Earth spinning on its axist.

2. Know that the Earth spins on its axis for 24 hours.

3. Know that the Earth takesa year to orbit the sun, spinning as it goes.

Research the lives and discoveries of scientists who explored the solar system and stars.

\section{METODE PENELITIAN}

\section{Pendekatan Penelitian}

Penelitian ini menggunakan pendekatan kualitatif deskriptif berdasarkan penelitian evaluatif, studi kasus siswa sekolah dasar Al azhar yang bersifat deskriptif melalui kegiatan studi kepustakaan, penelitian lapangan dan hasil analisis ujian akhir Cambridge Primary Check Point di bidang sains.

\section{Partisipan Penelitian}

Partisipan penelitian masih anak anak SD Al Azhar kelas 5 dan 6 tahun 2013, yang sama, yang mendaftarkan diri mereka untuk mengikuti ujian. peserta ujian tahun 2013 jumlahnya mencapai 61 siswa. Mereka telah lama belajar bahasa Inggris baik di kelas bilingual di al-Azhar maupun di tempat kursus di luar sekolah. Para guru di SD Al Azhar juga memberikan latihan soal materi pembelajaran Cambridge dibidang bahasa Inggris dan saints sebelum ujian sehingga mereka telah dibekali pola pola pembelajaran Cambridge Primary Check Point.

\section{Waktu dan Tempat}

Peserta ujian, telah disiapkan dengan cukup baik di bidang penguasaan bahasa Inggris dan sains. Sesuai dengan peraturan dari Cambridge, maka ujian dilaksanakan serentak pada bulan April tahun 2013. Ujian dilaksanakan di universitas AlAzhar di ruang Arifin Panigoro lantai 3 untuk kapasitas 60 siswa. Hasil lengkap nilai saints dan bahasa Inggris dikirim kembalike Indonesia beberapa bulan kemudian. Hasil akhir ujian berbentuk sertifikat kelulusan ujian Primary dari Cambridge yang akan dijadikan data dalam penelitian ini. untuk dianalisis. Rincian nilai dikelompokkan dalam nilai Science (overall),Biology, Chemistry, Physics dan Scientific enquiry. Ujian Cambridge Primary Checkpoint sains terdiri dari ujian untuk paper 1 dan paper 2 masing masing berlansung 45 menit.

\section{Metode Analisis Data}

Urutan pelaksanaan penelitian adalah sebagai berikut; pengumpulan data literature mengenai materi ujian sains sesuai dengan kurikulum dan silabus Cambridge pada sekolah dasar sampai kelas 5 dan enam siswa al Azhar di usia 13- 15 tahun. Kemudian menganalisis kandungan ESP dan EAP pada materi sains. Kemudian peneliti menganalisis hasil ujian Cambridge Primary Exams dalam sains untuk melihat tingkat kemampuan siswa 61 siswa SD Al Azhar dalam mata ajar sains. Setelah itu membandingkan hasil tes bahasa Inggris dengan hasil tes sains untuk melihat bagaimana kemampuan Bahasa Inggris mempengaruhi kemamapuan menjawab pertanyaan dalam sains. dan yang terakhir menarik kesimpulan faktor apa sajakah yang terlibat di dalam pemerolehan hasil nilai sains.

\section{TEMUAN DAN ANALISIS}

\section{Analisis Materi Cambridge International Primary Programme Science Tests}

Materi ujian terdiri atas paper 1 dan paper 2, yang masing masing terdiri dari pertanyaan pendek terstruktur dengan kandungan nilai 50 point. Seluruh pertanyaan harus dijawab dan setiap pertanyaan mencerminkan 1 jenis tujuan pembelajaran. Bidang ilmu yang diangkat dalam ujian sains ini adalah biologi, fisika, kimia dan kemampuan atau keterampilan dalam menganalisis secara sains. Pertanyaan dalam ujian beragam seperti menanyakan mengenai informasi keilmuan dan bagaimana mengaplikasikan ilmu sain stersebut Komposisi kedua jenis pertanyaan ber rasio 40:60, yang artinya $40 \%$ pertanyaan mengenai isi atau informasi bidang ilmu, dan $60 \%$ bagaimana mengaplikasikan ilmu tersebut. Penggunaan kalkulator dalam ujian diperbolehkan. Berikut ini adalah contoh pertanyaan ujian yang sumbernya berasal dari Cambridge

Contoh materi (1). Science Enquiry berikut kosa kata dalam bentuk frasa English for Academic Purposes dan/atau English for Specific Purposes (EAP/ESP) 
Gambar 1. Contoh Materi (1) Science Enquiry

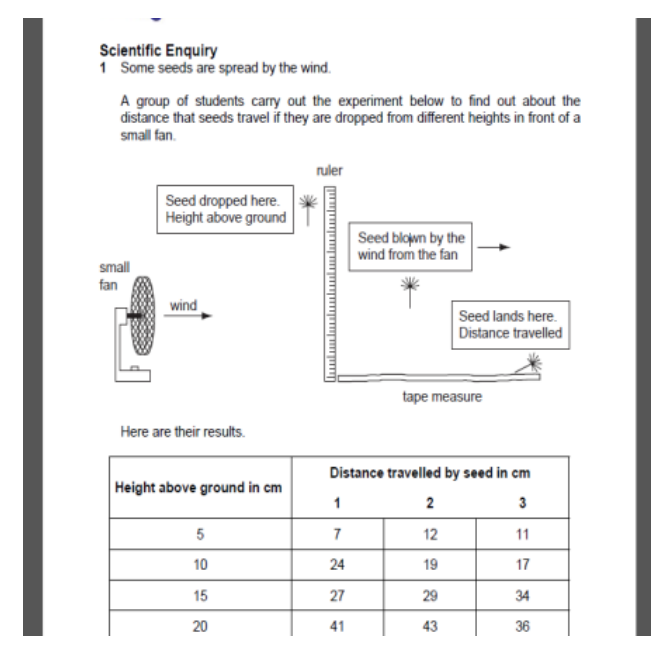

1. Scientific enquiry

2. Seeds travel

3. Height above the ground

4. Seeds land

5. Distance travelled

6. Affects the distance

7. Plot a line graph

8. To label the graph axes

9. On the $x$ axis

10. average results

Dalam frasa diatas, jelas terlihat bagaimana nomina seeds atau biji dan nomina Distance atau jarak diperlakukan sebagai mahluk hidup yang dapat bergerak. Frasa lain menjelaskan aktivitas nomina dan posisi nomina.

Contoh materi (2). Science Enquiry berikut kosa kata dalam bentuk frasa English for Academic Purposes dan/atau English for Specific Purposes ( EAP/ESP) seperti yang dijelaskan diatas

Gambar 2. Contoh Materi (2) Science Enquiry

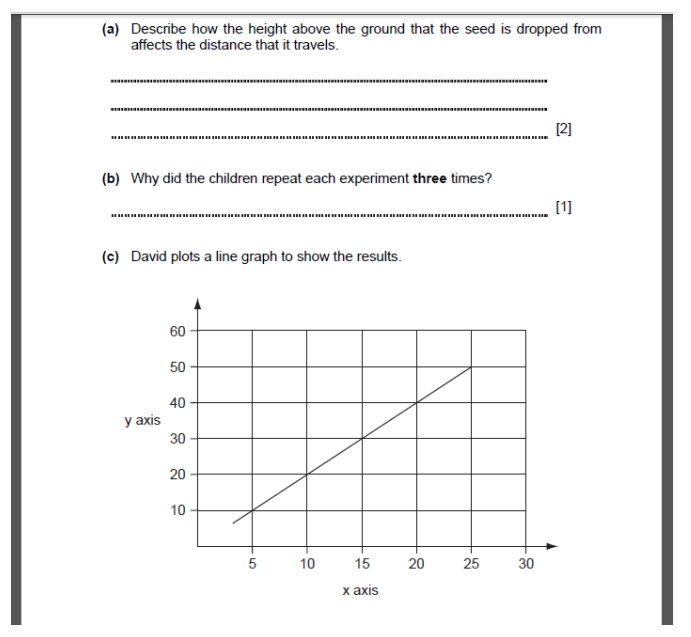

Jadi yang dimaksud dengan Scientific enquiry adalah bagaimana siswa mampu mengaplikasikan proses perkembangan suatu benda secara ilmiah dan terstruktur sebagai cerminan nalar yang logis dari cara berpikir siswa tersebut.

Contoh materi (3). Biologi berikut kosa kata dalam bentuk frasa English for Academic Purposes dan/atau English for Specific Purposes (EAP/ESP)

\section{Gambar 3. Contoh Materi (3) Biologi}

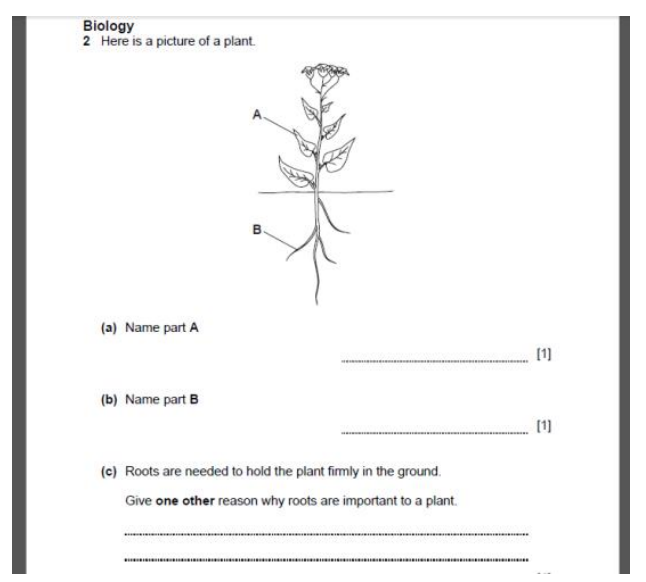

Dalam ESP/EAP kalimat banyak berstruktur present passive tense karena bertujuan mengutamakan penjabaran Nomina sebagai pokok bahasan seperti diatas mengenai pentingna akar tumbuhan. Disamping tumbuhan, biologi menjelaskan tentang mahluk hidup lainnya seperti manusia dan binatang. Contoh frasa mengenai binatang pada tingkat primary ini adalah:

Insectivorous birds, predaceous insects, herbivorous insects, seed-eating birds, food chains for mice. Atau terminologi dalam biologi ketika menjelaskan makna pemakan seperti predator, prey dan produce. Dengan demikian dapat ditarik kesimpulan bahwa siswa SD dari kelas 3, 4, 5 dan 6 sudah diberi kosa kata yang sangat luas mengenai mahluk hidup di dunia berikut kharakter maupun pola kehidupan mahluk hidup di bumi sebagai suatu ekosistim dan lingkungan ini dalam bahasa Inggris.

Contoh materi (4). Fisika berikut kosa kata dalam bentuk frasa English for Academic Purposes dan/atau English for Specific Purposes ( EAP/ESP) 
Gambar 4. Contoh Materi (4) Fisika

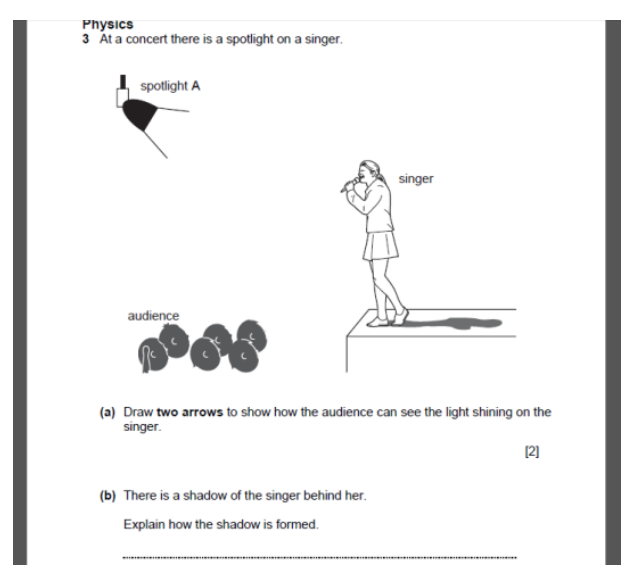

Contoh kosa kata dalam fisika seperti: how the shadow is performed, the light shining on, the earth spins on its axis, units of forcé, the notion of energy in movement. Fisika untuk ujian SD mencakup kosakata yang menjelaskan cahaya seperti diatas, daya Tarik, bunyi , listrik dan magnet. Kosa kata dalam paper 2 lainnya tentang bunyi misalnya: glockenspiel, records the loudness of the sound in decibels, make a high pitched sound

Contoh materi (5). Kimia berikut kosa kata dalam bentuk frasa English for Academic Purposes dan/atau English for Specific Purposes ( EAP/ESP)

Gambar 5. Contoh Materi (5) Kimia

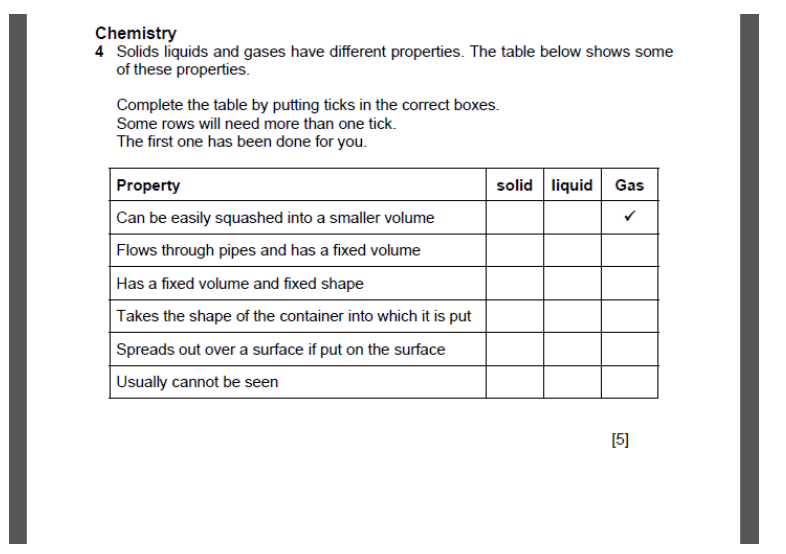

Kosa kata kimia meliputi material dan properti yg berkarakter keras, lembut, berkilat dan sebagainya dan sebagian dari material memiliki sifat magnetis contoh material dan propertinya: solid liquids, gases, smaller volume, fixed volume, fixed shape, water turns to steam, the steam turns to water, condensation is the reverse of evaporation.

Paparan materi ujian Primary menyimpulkan bahwa kosa kata dalam mata ajar dan ujian tingkat
SD mewajibkan murid untuk mengusai bahasa Inggris pada tingkat penguasaan bahasa Inggris untuk Academic maupun Specific purposes karena kosa kata yang tercermin dalam ujian sains bukan menggunakan bahasa Inggris dasar atau bahasa Inggris percakapan. Penguasaan ESP/EAP pada tingkat SD bukan hanya bahasa akademik dasar saja tetapi juga lebih luas karena mereka harus menjelaskan dengan cara ilmiah pada tataran yang beragam yakni: biologi (manusia, binatang, tumbuhan, ekosistim dan lingkungan); Kimia (materi dan properti, perubahan materi, dan state of matter); Fisika (listrik dan magnet, tekanan dan motion, cahaya, bunyi, dunia dan tatasurya, Scientific enquiry, (mencari data, merencanakan, mempresentasikan dan mencari pembuktian).

\section{Analisis Hasil Ujian Cambridge International Primary Programme Sains May 2013}

Hasil ujian Cambridge Primary untuk 61 siswa SD Al-Azhar diserahkan 3 bulan setelah ujian selesai dalam bentuk sertifikat bagi para murid dan laporan nilai kepada Centre CIE of UAI. Rinciannya adalah sebagai berikut:

$\begin{array}{ll}\text { Science (overall) } & \text { Average score }=4.1 \\ \text { Biology } & \text { Average score }=4.1 \\ \text { Chemistry } & \text { Average score }=4.2 \\ \text { Phyisics } & \text { Average score }=4.1 \\ \text { Science enquiry } & \text { Average score }=40\end{array}$

Penjelasan skala perolehan adalah Cambridge Primary Checkpiont adalah:

1. skala nilai 0.0 ( kemampuan terendah) sampai 6 (kemampuan tertinggi).

2. Siswa yang mendapat nilai3.0 dan 4.0. berarti telah memiliki pengertian cukup luas dari materi kurikulum Cambridge

3. Siswa yang mendapat nilai 2.0 hanya memiliki kemampuan dasar dari pemahaman materi kurikulum Cambridge.

4. Siswa yang memiliki nilai 5.0 keatas memiliki kemampuan pemahaman yang sangat memuaskan dari materi kurikulum Cambridge.

Secara keseluruhan dari 61 siswa, maka dapat dikatakan bahwa mereka berada ditingkat penilaian memiliki kemampuan yang luas atau menengah di hampir semua bidang studi dengan urutan tertinggi kimia dan diikuti oleh nilai sama pada biologi, fisika dan science enquiry. Namun análisis akan kemudian diperinci kepada capaian yang mengerucut melalui rincian performa di sub bagian dan nilai individu siswa. 
Hasil capaian performa dalam sub-bidang adalah sebagai berikut:

\begin{tabular}{|c|c|c|}
\hline$B h$ & Human and animals & Performance was as expected \\
\hline $\mathrm{Be}$ & Living things in their environment & Performance was as expected \\
\hline$B p$ & Plants & Performance was as expected \\
\hline \multicolumn{3}{|c|}{ Chemistry } \\
\hline Cc & Material change & Performance was as expected \\
\hline$C p$ & Material Properties & Performance was as expected \\
\hline Cs & States of matter & Performance was as expected \\
\hline \multicolumn{3}{|c|}{ Physics } \\
\hline$P m$ & Electricity and magnetism & Performance was worse than expected \\
\hline Pf & Forces and motion & Performance was as expected \\
\hline$P I$ & Light and dark & Performance was worse than expected \\
\hline Ps & Sound & Performance was as expected \\
\hline$P b$ & The earth beyond & Performance was as expected \\
\hline \multicolumn{3}{|c|}{ Scientific enquiry } \\
\hline \multicolumn{2}{|c|}{ Eo-obtaining, presenting and considering evidence } & Performance was as expected \\
\hline \multicolumn{2}{|c|}{ Ep-Planning from ideas and evidence } & Performance was worse than expected \\
\hline
\end{tabular}

Dari data di atas terlihat bahwa siswa mendapat nilai baik dari pemahaman biologi dan kimia di setiap sub topik bahasan, namun dalam fisika di butir kelistrikan dan pencahayaan performanya masih jauh dibawah harapan dan pada scientific enquiry kondisi buruk terjadi di tingkat bagaimana merencanakan gagasan atau ide dan bukti bukti. Hal ini dapat dipahami karena bidang kelistrikan dan pencahayaan mungkin kurang dieksploitasi didalam kelas oleh para guru di Al Azhar. Sedangkan untuk butir Science enquiry, kesulitan terjadi karena pertama, para siawa sudah mendapat kesulitan di penguasaan bahasa Inggris secara akademik di empat topik dalam sains, kedua, ditambah dengan kesulitan menjelaskan secara deskriptif akademik dalam bahasa Inggris pada ke empat topik.

Evaluasi kelompok nilai di komponen Biologi (B), Kimia (K), Fisika (P) dan Science enquiry (Se). Berikut ini akan dijelaskan berapa siswa yang mendapat nilai di angka 1, 2, 3, 4, 5, dan 6 pada komponen mata ajar dalam sains di Cambridge Primary check Point, untuk mendapatkan gambaran berapa jumlah siswa yang berada ti tingkat kemampuan tertentu pada mata ajar masing masing.

Tabel 2. Jumlah mahasiswa berdasarkan perolehan nilai sub sains.

\begin{tabular}{ccccc}
\hline nilai & Biologi & Chemistry & Physics & $\begin{array}{c}\text { Science } \\
\text { enquiry }\end{array}$ \\
\hline $0.0-0.9$ & $\mathbf{0}$ & 1 & 1 & $\mathbf{3}$ \\
\hline $1.0-1.9$ & 3 & 4 & 5 & 3 \\
\hline $2.0-2.9$ & 11 & 7 & 7 & 4 \\
\hline $3.0-3.9$ & 9 & 15 & $\mathbf{1 6}$ & $\mathbf{1 8}$ \\
\hline $4.0-4.9$ & $\mathbf{2 1}$ & 15 & 11 & 14 \\
\hline $5.0-5.96$ & 9 & $\mathbf{1 6}$ & 5 & 12 \\
\hline 6.0. & 8 & 3 & $\mathbf{1 6}$ & 7 \\
\hline TOTAL & $\mathbf{6 1}$ & $\mathbf{6 1}$ & $\mathbf{6 1}$ & $\mathbf{6 1}$ \\
\hline
\end{tabular}

Jumlah siswa yang paling banyak mendapat angka 0 adalah pada bidang Science enquiry yang mengindikasikan bahwa ada murid yang tidak mampu memiliki strategi mendeskripsikan jawaban pertanyaan secara akademis. Alam skala nilai 1 sampai 6, paling besar jumlah siswa menduduki nilai 3 pada Science enquiry yang mencerminkan bahwa muris SD al azhar kebanyakan memiliki kemampuan di nilai sedang (3), walau 7 siswa mendapat nilai tertinggi.

Fisika merupakan mata pelajaran yang paling favorite bagi siswa karena nilai tertinggi 6 dikuasai oleh jumlah murid terbanyak yakni 16 orang sama besar dengan jumlah di nilai 3. Apabila siswa yang mendapat nilai 5 dan siswa yang mendapat nilai 6 digabung, maka jumlah yang terbesar ada dalam bidang studi fisika yakni sebanyak 21 siswa atau seperempat dari jumlah total murid. Nilai 5 keatas merupakan siswa dengan kualitas teristimewa dimana mereka memiliki 'an excellent understanding of the curriculum content'.

Pada mata pelajaran Kimia terlihat adanya pemahaman yang lebih menyeluruh dengan jumlah yang signifikan dinilai 3,4 , dan 5 dengan jumlah 46 siswa yan berarti 75 persen siswa memiliki pemahaman luas (advanced) di pelajaran kimia. Namun ironisny memiliki jumlah 3 murid yang merupakan jumlah paling sedikit di banding dengan bidang lainnya, di nilai tertinggi yakni nilai 6 .

Pada biologi terdapat distribusi jumlah siswa di masing masing nilai secara imbang diluar 21 murid pada nilai 4 dan tidak satupun mendapat nilai 0 . Dalam biologi jumlah terbesar ada di nilai 2, 3, dan 4. Dari semua peserta nama mahasiswa pada tabel 3 adalah siswa yang memiliki nilai tertinggi.

Tabel 3. Nama mahasiswa berdasarkan perolehan nilai tertinggi ( 50 dan 60)

\begin{tabular}{lcccc}
\hline \multicolumn{1}{c}{ Nama } & Biologi & Chemistry & Physics & $\begin{array}{c}\text { Science } \\
\text { enquiry }\end{array}$ \\
\hline $\begin{array}{l}\text { 1.Sathya } \\
\text { Aisha T }\end{array}$ & $\mathbf{5 8}$ & 59 & 56 & $\mathbf{5 1}$ \\
\hline $\begin{array}{l}\text { 2.Davina } \\
\text { Nurul }\end{array}$ & 60 & 46 & 60 & 51 \\
\hline $\begin{array}{l}\text { 3.Sekar } \\
\text { Prabhandiya }\end{array}$ & 60 & 60 & 60 & 60 \\
\hline $\begin{array}{l}\text { 4.Ahmad } \\
\text { Izzudin }\end{array}$ & 53 & 60 & $\mathbf{6 0}$ & $\mathbf{6 0}$ \\
\hline $\begin{array}{l}\text { 5.Rangga } \\
\text { fardan Lailan }\end{array}$ & $\mathbf{6 0}$ & 54 & 60 & 60 \\
\hline $\begin{array}{l}\text { 6.Fairuz } \\
\text { Andini }\end{array}$ & 60 & $\mathbf{6 0}$ & 60 & 42 \\
\hline
\end{tabular}


Data pada tabel 3 terlihat bahwa Sekar, misalnya sudah memiliki kemahiran yang sama dengan siswa yang menggunakan bahasa Inggris sebagai bahasa ibu. Juga ke 5 siswa lainnya juga mendekati 'native speakers' Karen nilainya hanya sedikit dibawah pencapaian nilai siswa bernama Sekar. Peserta bernama Ahmad Izzudin A ternyata adalah bukan saja menjadi salah satu siswa terbaik di bidang sains tetapi juga satu satunya yang mendapat nilai 6 (tertinggi) dalam ujian Cambridge Primary bahasa Inggris. Ini mengidentifikasikan bahwa apabila siswa mampu menguasai bahasa Inggris dengan sempurna maka kemungkinan dapat nilai tinggi di pelajaran sains bisa terwujudkan. Dalam kasus Sekar, ia mendapat 6.0 untuk semua mata ajar yang ada dalam sains tetapi nilai bahasa Inggrisnya ada di bawah nilai 6.0 .

\section{Perbandingan Hasil Ujian Bahasa Inggris dengan Sains}

Data yang telah di ulas dalam penelitian terdahulu mengenai hasil ujian bahasa Inggris Cambridge primary adalah

English (overall)
Reading
Usage
Writing

Nilai rata rata $=3.1$

Nilai rata rata $=3.6$

Nilai rata rata $=2.8$

Nilai rata rata $=2.5$

Dengan siswa yang sama capaian hasil ujian sains menunjukkan hasil rerata yang lebih baik seperti berikut:

$\begin{array}{ll}\text { Science (over all) } & \text { Nilai rata rata }=4.1 \\ \text { Biologi } & \text { Nilai rata rata }=4.1 \\ \text { Chemistry } & \text { Nilai rata rata }+4.2 \\ \text { Physics } & \text { Nilai rata rata }=4.1 \\ \text { Scientific enquiry } & \text { Nilai rata rata }=4.0\end{array}$

Tabel 4. Jumlah mahasiswa berdasarkan perolehan nilai sub sains.dan bahasa Inggris

\begin{tabular}{|c|c|c|c|c|c}
\hline Nilai & English & Biologi & Chemistry & Physics & $\begin{array}{c}\text { Science } \\
\text { enquiry }\end{array}$ \\
\hline $0.0-0.9$ & 11 & $\mathbf{0}$ & 1 & 1 & $\mathbf{3}$ \\
\hline $1.0-1.9$ & 7 & 3 & 4 & 5 & 3 \\
\hline $2.0-2.9$ & 16 & 11 & 7 & 7 & 4 \\
\hline $3.0-3.9$ & 13 & 9 & 15 & $\mathbf{1 6}$ & $\mathbf{1 8}$ \\
\hline $4.0-4.9$ & 11 & $\mathbf{2 1}$ & 15 & 11 & 14 \\
\hline $5.0-5.96$ & 2 & 9 & $\mathbf{1 6}$ & 5 & 12 \\
\hline 6.0. & 1 & 8 & 3 & $\mathbf{1 6}$ & 7 \\
\hline TOTAL & $\mathbf{6 1}$ & $\mathbf{6 1}$ & $\mathbf{6 1}$ & $\mathbf{6 1}$ & $\mathbf{6 1}$ \\
\hline
\end{tabular}

Data tabel 4 memperlihatkan kisaran tingkat kemampuan terbanyak pada setiap bidang pelajaran. Tingkat kemahiran bahasa Inggris dicapai pada nilai 2, 3 dan 4 yang berarti penguasaan Bahasa Inggris berada di level dasar hingga upper intermediate. Pada biologi juga terjadi hal yang sama di kemampuan nilai2, 3,dan 4. Dan ini mencerminkan bahwa kedua bidang pelajaran ini termasuk sulit untuk dikuasai murid karena cakupan ilmunya yang cukup luas. Pertama bahasa Inggris yang dituntut adalah Bahasa Inggris baku dan bersifat akademik. Sedangkan dalam biologi, cakupan wawasan berupa pengetahuan tentang manusia,binatang, tanaman dan lingkungan hidup serta alamnya.

Kimia dan Science enquiry memiliki persamaan dalam capaian pemahaman ilmu bagi siswa $\mathrm{Al}$ Azhar, namun berbeda dengan Inggris dan biologi, tingkat capaiannya lebih tinggi yakni terkonsentrasi di kemamapuan mengerjakan secara memuaskan di nilai 3, 4, dan 5. Hasil ini sangat menggembirakan karena ternyata para siswa mampu mengusai tingkat intermediate dan advance sekaligus.

Terakhir mengenai penguasaan di bidang fisika. Nilai tertinggi ada pada angka3, 4, dan 6, karena pada nilai tertinggi 6 terdapat 16 siswa yang berhasil maka, fisika adalah bidang ilmu yang paling dikuasai oleh para murid. Ternyata siswa kita dapat disejajarkan dengan anak SD yang menggunakan Bahasa Inggris sebagai bahasa ibu atau Bahasa pertama mereka.

\section{SIMPULAN DAN SARAN}

Penelitian ini memperlihatkan adanya materi bernuansa ESP/EAP pada tingkat sekolah dasar dalam mata pelajaran lain di luar pelajaran bahasa Inggris. Bahasa Inggris akademik mulai dari yang paling dasar dan berkembang dengan berurutan secara alami sehingga siswa tidak merasa sedang mengerjakan tugas akademik, tapi merasakannya sebagai pembelajaran biasa dan secara psikologis siswa merasa sangat nyaman mengerjakan beragam jenis tugas akademik dalam sains. Keberhasilan pemahaman sains dalam bahasa Inggris membuktikan bahwa pemerolehan bahasa ke dua pada anak usia sekitar 13 tahun adalah masa emas untuk belajar Bahasa.

Siswa sekolah dasar sudah diberikan tugas yang berat dalam mempelajari bahasa Inggris karena materi yang mereka kerjakan bukan hanya bahasa akademik dasar saja tetapi lebih luas menjelaskan dengan cara ilmiah pada tataran yang beragam yakni: biologi (manusia, binatang, tumbuhan, 
ekosistim dan lingkungan); Kimia (materi dan properti, perubahan materi, dan state of matter); Fisika (listrik dan magnet, tekanan dan motion, cahaya, bunyi, dunia dan tatasurya; Scientific enquiry, (mencari data, merencanakan, mempresentasikan dan mencari pembuktian). Setiap bidang memiliki genre tertentu yang harus dikuasai siswa dan ini memberikan pengetahuan yang sangat luas pada murid SD.

Penguasaan bidang pelajaran menurut hasil ujian tercatat sebagai berikut: yang paling mudah atau dikuasai adalah fisika. Biologi dan kimia sedikit lebih sulit dan yang paling sulit adalah science enquiry. Karena nilai bahasa Inggris terkonsentrasi di kemampuan nilai 2 dan 3 maka, kurang kuatnya pemahaman bahasa terlihat berdampak terutama di bidang Science enquary karena bidang ini menuntut penjelasan tertulis secara deskritif bernalar dalam sains. Jumlah terbanyak ada di nilai 3 sebanyak 18 siswa. Hal ini juga tercermin dalam hasil biologi.

Bidang biologi menuntut kosa kata yang luas mengenai mahluk hidup di dunia berikut perilaku mereka sehingga membutuhkan pendalaman bahasa Inggris untuk dapat menjelaskan bidang biologi yaitu di nilai 4 sebanyak 21 siswa. Sementara, Kimia didominasi di nilai 5 dengan perolehan jumlah terbanyak 16 siswa. Pelajaran kimia memiliki topik bahasan yang lebih kecil daripada biologi, terkonsentrasi pada benda atau materi padat cair dan gas berikut karakternya dan perubahan yang terjadi pada benda benda tersebut.

Fisika seperti yang telah diuraikan diatas menjadi mata pelajaran termudah karena jumlah terbanyak yaitu 16 siswa berada pada nilai tertinggi 6 . Nilai 6 sama dengan nilai 100 yang berarti semua jawaban dalam posisi benar. Hal ini membuktikan bahwa kemampuan di bidang fisika, walau harus diuraikan dalam bahasa Inggris, siswa mampu mengerjakan dengan sempurna layaknya siswa Inggris asli. Hasil yang mengejutkan ini bisa dilihat dari berbagai sudut pandang. Kemungkinan pertama, para siswa sangat menggemari bidang fisika. Kedua, Semua guru fisika al Azhar memiliki kemampuan yang sangat baik bahkan hampir sempurna dalam mendidik murid muridnya. Perlu diketahui bahwa 61 siswa Alazhar ini terdiri dari beberapa sekolahAlazhar di jakarta dan sekitarnya. Ketiga, Materi ujian fisika jauh lebih mudah dibandingkan dengan materi biologi, kimia maupun science enquiry.
Dilihat dari jumlah siswa terbanyak mendapatkan nilai tertentu pada bidang pelajaran adalah: Bahasa Inggris ada di nilai 2 (16 siswa), Biologi ada di nilai 4 (21 siswa), Kimia ada di nilai 5 (16 siswa), Fisika ada di nilai 3 dan 6 ( 16,16 siswa) dan Science inquiry ada di nilai 3 (18 siswa).

Untuk mendapatkan hasil nilai ujian Cambridge primary science yang lebih baik maka disarankan:

1. Siswa di SD mendapat pembelajaran bahasa Inggris yang sempurna baik dari metodologi maupun dari isi karena akan menjadi modal utama untuk melangkah dan mengembangkan ilmu lainnya.

2. Siswa harus dibiasakan mengerjakan tugas tugas bernuansa berpikir kritis dalam sains.

3. Guru harus meluangkan waktu untuk melatih cara menjawab tugas pada science enquiry sehingga siswa terbiasa untuk menjawab pertanyaan di bidang ini dengan baik.

4. Siswa harus dibiasakan mengerjakan eksperiment dengan topik yang luas dan berkaitan dengan lingkungan dan alam

5. Siswa harus dibiasakan menulis buku harian akademik sebagai refleksi pengalaman belajar.

6. Siswa diwajibkan mengikuti ujian Cambridge International Primary checkpoint sebagai pengalaman akademis berskala internacional

7. Ujian Cambridge International Primary Checkpoint akan menguntungkan siswa dan institusi Al Azhar karena telah menerapkan standar pendidikan internasional.

8. Siswa akan mendapat sertifikat yang akan memudahkan mereka masuk sekolah diluar negeri.

9. Pola pendidikan dan metodologi pengajaran yang siswa dapatkan akan menjadi rujukan ketika mereka akan sekolah diluar negeri baik ditingkat smp atau sma karena Cambridge memiliki alur pendidikan yang berkelanjutan.

10. Siswa yang sudah mengenyam pendidikan Cambridge Primary checkpoint dapat lebih mudah mempelajari bidang studi lainnya di SMA seperti History, Literature, Business, computer science dan lainnya

\section{DAFTAR PUSTAKA}

[1] Departmen Pendidikan Nasional, Panduan Penyelenggarann Program Rintisan SMA Bertaraf Internasiona, Jakarta : Direktorat Pembinaan Sekolah Menengah Atas, 2009. 
[2] University of Cambridge International Examinations, Primary English Curriculum Framework, Cambridge UK, www.cambridge.org, 2006.

[3] Robinson, Pauline, ESP Today: A Practitioner's Guid,. Prentice Hall: New York, 1991.

[4] J. Richards, Renandya .W, Methodology in Language Teaching. Cambridge University Press: Cambridge, 2002.

[5] D. Brown, Prinsip Pembelajaran dan Pengajaran Bahasa, Pearson Education .Inc, 2008.
[6] Harmer, Jeremy, The Practice of english Language Teaching, Longman publishing:New York, 1991.

[7] Larsen, Freeman, Diane, Techniques and Principles in Language Teaching. Oxford University Press: Oxford, 2008.

[8] D. Nunan, Language Teaching Methodology. Prentice Hall: Sydney, 1991.

[9] D. Soeyono, Psikolinguistik: Pengantar Pemahaman Bahasa manusia, Jakarta: Unika AtmaJaya, 2003. 